\title{
MICROMETEOROLOGICAL MEASUREMENTS OF FOGGY SITUATIONS IN SIÓJUT (NOVEMBER - DECEMBER, 2018)
}

\author{
Arun Gandhi ${ }^{(1)}$, András Zénó Gyöngyösi ${ }^{(1,2)}$, Ágoston Vilmos Tordai ${ }^{(1)}$ \\ Péter Torma $^{(3)}$ (D), András Rehák ${ }^{(3)}$, Mariann Szilágyi ${ }^{(3)}$, Ákos Horváth ${ }^{(4)}$ (D), \\ Tamás Weidinger ${ }^{(1)}$ (i) \\ (1) Department of Meteorology, Eötvös Loránd University, H-1117, Budapest, Hungary \\ (2) Department of Analytical Chemistry, Eötvös Loránd University, H-1117, Budapest \\ ${ }^{(3)}$ Department of Hydraulic and Water Resources Engineering, \\ Budapest University of Technology and Economics, Budapest, Hungary \\ (4) Hungarian Meteorological Service, Vitorlás u. 17, H-8600 Siófok, Hungary \\ e-mail: arun.elte@gmail.com, weidi@caesar.elte.hu
}

\section{Introduction}

Fog is defined as a suspension of water droplets and ice particles that reduce the visibility to less than $1 \mathrm{~km}$ near the Earth's surface. It is also described as a formation of low status cloud that forms near the Earth's surface. Its depth and horizontal extent depends upon surface characteristics, micro- and mesoscale meteorological factors such as radiation and turbulent characteristics.

Fog is a major weather hazard as it reduces visibility and can disrupt road, rail, and air transport. Therefore, reliable fog forecasting becomes essential to prevent interruptions in transportation (Michaelides et al., 2014; Vajda et al., 2014). Accurate fog forecasting relies on correct parameterizations of the radiative, turbulent and surface processes as poor parameterization lead to poor forecasting results (Westerhuis et al., 2020). Statistical investigations of fog formation and development are also important for the climatological background of secure aviation (Wantuch \& Michaelides, 2005; Bottyán et al., 2010; Tuba \& Bottyán, 2018). Therefore, it is essential to understand the physical, chemical, and meteorological features that lead to fog generation, preservation, and dissipation. As a result, ground-based fog experiments are being conducted in different cities worldwide to formulate better parameterizations for fog modelling. Ground-based fog experiments have been conducted for example in Paris, New Delhi or Wasatch Mountain Range (northern Utah, USA), to measure the fog events, associated thermodynamics, microphysics, and chemical composition of gases and aerosols (Haeffelin et al., 2010; Gultepe et al., 2016; Ghude et al., 2017).

This study consists of two main parts. First, a comparison of fog climatology among New Delhi, Budapest, and Siófok is provided. It was done to assess the frequency and occurrence of fog in the three cities. The second part of the manuscript describes the micrometeorological measurement campaign in Siójut (Hungary) from 15th October 2018 till 13th December 2018. Measuring system, main goals of the experiment and few results are presented. The momentum $(\tau)$ and sensible heat $(H)$ fluxes were calculated based on eddy covariance methodology using Gill sonic anemometer. Necessary corrections were applied to the raw eddy fluxes as described in the TK3 software manual (Weidinger et al., 1999; Barcza, 2001; Mauder \& Foken, 2015 and Horváth et al., 2018). We measured the surface and soil energy budget components together with the heat flux into the soil $\left(G_{-} S o i l\right)$ and net radiation $(R n)$. Finally, case studies of fog events are presented to show the daily variation of meteorological variables, radiation, and surface energy budget components. 


\section{Fog climatology in New Delhi, Budapest and Siófok - comparison study}

Synoptic data for New Delhi (42181), Siófok (12935), and Budapest (12843) was obtained from Meteomanz website (http://www.meteomanz.com/) for the months from October to March. The data was obtained for the periods 2017-18 and 2018-19. The synoptic data was used to analyse the climatology of fog and mist in the three cities and then a comparison was made among them based on the number of fog and mist events and their duration. An event is classified as fog or mist if continuous fog or mist was observed in the synoptic data for at least 3 hours. Further, an event was classified as mist if the visibility was between $1 \mathrm{~km}$ to $5 \mathrm{~km}$ and as fog if the visibility was less than $1 \mathrm{~km}$.

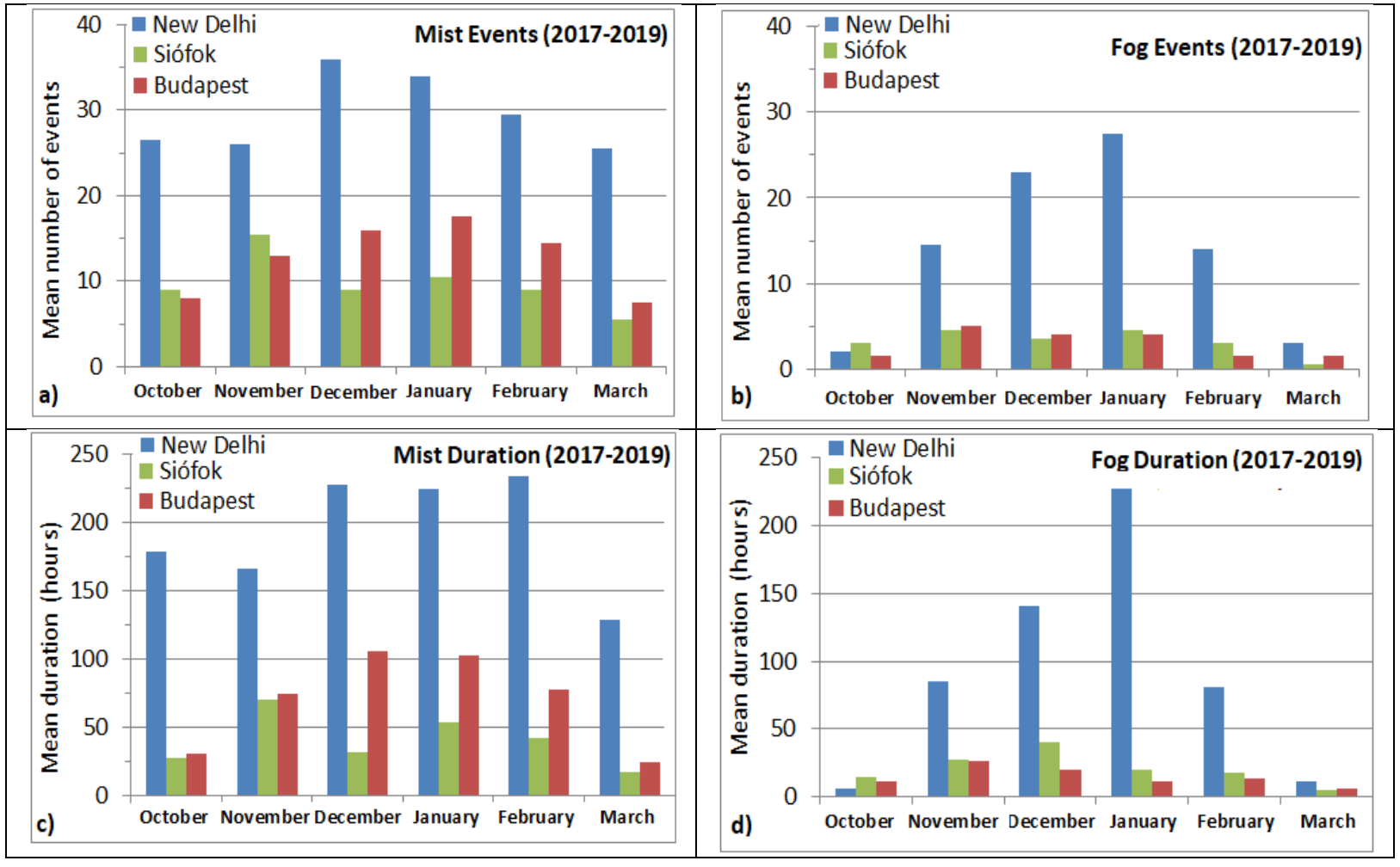

Figure 1. Number and duration of mean monthly mist $(\mathrm{a}, \mathrm{c})$ and fog $(\mathrm{b}, \mathrm{d})$ events in New Delhi, Siófok, and Budapest for October to March season (2017-2019).

Values of mist and fog events have been averaged out over the 2-year period.

Comparing the fog climatology from 2017-2019 for the months October to March (Fig. 1) showed that the number of fog events as well as their durations in New Delhi were around 4 to 5 times more than in Budapest and Siófok during December and January. For November and February, the number of events and durations of fog were 2 to 3 times higher in Delhi than in Budapest and Siófok. Mist events and durations in Delhi were 2 to 3 times higher than Budapest and Siófok for the whole period. For all three cities the number of fog and mist events, as well as their durations, was highest in December and January. The lowest numbers for mist and fog events were recorded for October and March.

Recent events of extremely high pollution in India's capital can be attributed to an increased number of misty and foggy days (Liu et al., 2018). During winter, the pollutants from several industrial sources, crop burning in villages and vehicular exhaust get locked in the lower atmosphere due to stagnant winds. Further sand and dust generated from construction activities form a suspension of aerosol particles allowing settling of fog and mist droplets resulting in fog generation. 


\section{Siójut field campaign}

The Siójut Fog Experiment was conducted near the Sió Channel $6 \mathrm{~km}$ from Siófok (Lake Balaton) with the participation of: University of Pannonia (mobile air quality lab), University of Pécs, Hungarian Meteorological Service, and ELTE Department of Meteorology from middle of October to middle of December 2018.

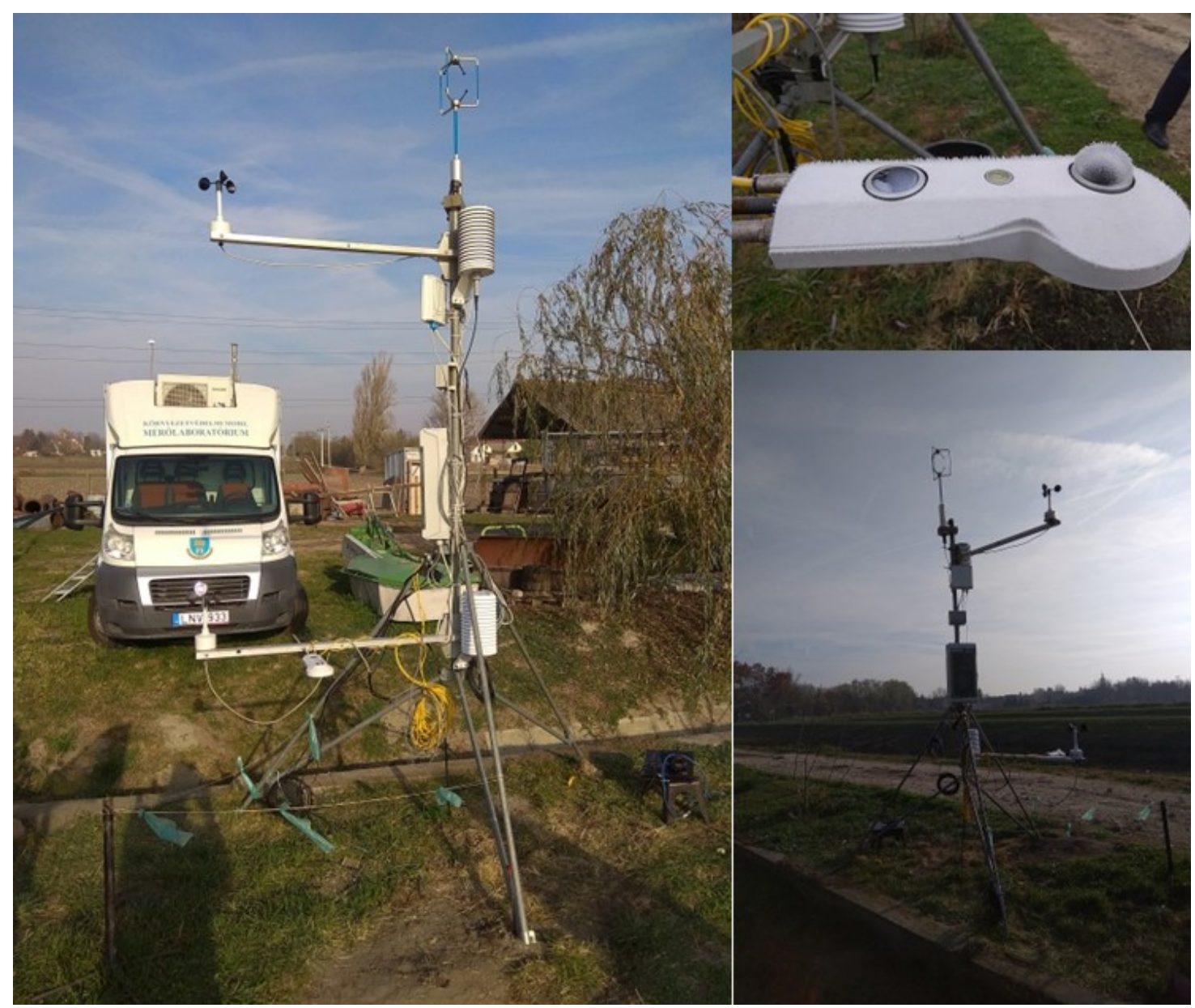

Figure 2. Micrometeorological observation pole and its instrumentation (CNR4 net radiometer, Gill sonic anemometer, temperature, relative humidity, and wind speed gradients). Mobile air chemistry laboratory of the University of Pannonia in the background.

Micrometeorolgical measurement pole and instrumentation are presented in Fig. 2. Soil measurements consisted of soil temperature, soil moisture, and heat flux in the upper $10 \mathrm{~cm}$ soil layer using Campbell Scientific Instruments. The instruments deployed in the field and the description is given in Table 1. CR1000 data logger was used to obtain the 1-minute averaging data set and Raspberry computer for $10 \mathrm{~Hz}$ data set. Raw data from Gill sonic anemometer was used for flux (momentum $(\tau)$ and sensible heat $(H)$ ) calculation.

Surface temperature was measured based on the temperature and long wave radiation from CNR4 sensor. Temperature and relative humidity differences between $1 \mathrm{~m}$ and $2.7 \mathrm{~m}$ were measured with Vaisala HMP45 sensors. Leaf wetness was measured with a leaf wetness grid. Two Vaisala (recalibrated in the laboratory) WAA15 wind speed sensor $(1.25 \mathrm{~m}$ and $3 \mathrm{~m})$ were used to measure the wind speed. 
Gandhi, A., Gyöngyösi, A.Z., Tordai, V.Á., Torma, P., Rehák, A., Szilágyi, M., Horváth, Á., Weidinger, T.: Micrometeorological measurements on foggy situations in Siójut (November - December, 2018)

Table 1: Instrumentation used on the micrometeorological experiment in Siójut, 2018

\begin{tabular}{|c|c|c|c|c|}
\hline No & Instrument & Height & Variables & Comment \\
\hline $\mathrm{A}$ & $\begin{array}{l}\text { Raspberry } \\
\text { computer for data } \\
\text { collection }\end{array}$ & $2.8 \mathrm{~m}$ & $\begin{array}{l}\text { Data collection for Gill sonic } \\
\text { anemometer }\end{array}$ & $\begin{array}{l}10 \mathrm{~Hz} \text { time resolution, daily } \\
\text { files, close connection with } \\
\text { the Telktonika modem }\end{array}$ \\
\hline 1. & $\begin{array}{l}\text { Gill Sonic, } \\
\text { WindMaster }\end{array}$ & $3.4 \mathrm{~m}$ & $\begin{array}{l}\text { Wind Speed Components } \\
(u, v, w)[\mathrm{m} / \mathrm{s}] \\
\text { Sound Speed }(c)[\mathrm{m} / \mathrm{s}], \\
\text { Sonic Temperature }\left(T_{\text {sonic }}\right)[\mathrm{K}]\end{array}$ & $\begin{array}{l}\text { Old version, no vertical wind } \\
\text { speed correction }\end{array}$ \\
\hline B & $\begin{array}{l}\text { CR1000+ } \\
\text { Telktonika } \\
\text { modem }\end{array}$ & $1.6 \mathrm{~m}$ & $\begin{array}{l}\text { Voltage }[\mathrm{V}] \\
\text { Panel Temperature }\left(T_{\text {panel }}\right)\left[{ }^{\circ} \mathrm{C}\right] \\
\text { Reference Temperature }\left(T_{\text {ref }}\right)\left[{ }^{\circ} \mathrm{C}\right]\end{array}$ & $\begin{array}{l}5 \mathrm{~s} \text { sampling rate, } \\
1 \text { min averaging time } \\
\text { for all variables }\end{array}$ \\
\hline 2. & Vaisala WAA15 & $3.0 \mathrm{~m}$ & $\begin{array}{l}\text { Wind Speed }(U) \\
\quad(\text { mean, max, std.) }[\mathrm{m} / \mathrm{s}]\end{array}$ & Cap anemometer \\
\hline 3. & Vaisala WAA15 & $1.25 \mathrm{~m}$ & $\begin{array}{l}\text { Wind Speed }(U) \\
\text { (mean, max, std.) }[\mathrm{m} / \mathrm{s}]\end{array}$ & Cap anemometer \\
\hline 4. & Vaisala HMP45 & $2.7 \mathrm{~m}$ & $\begin{array}{l}\text { Temperature }(T)\left[{ }^{\circ} \mathrm{C}\right], \text { and } \\
\text { relative humidity }(R h)[\%]\end{array}$ & $\begin{array}{l}\text { With shield from Campbell } \\
\text { Scientific }\end{array}$ \\
\hline 5. & Vaisala HMP45 & $1.0 \mathrm{~m}$ & $\begin{array}{l}\text { Temperature }(T)\left[{ }^{\circ} \mathrm{C}\right], \text { and } \\
\text { relative humidity }(R h)[\%]\end{array}$ & $\begin{array}{l}\text { With shield from Campbell } \\
\text { Scientific }\end{array}$ \\
\hline 6. & $\begin{array}{l}\text { Kipp \& Zonen, } \\
\text { CNR4 } \\
\text { Net Radiometer }\end{array}$ & $0.75 \mathrm{~m}$ & $\begin{array}{l}\text { Net Radiation, shortwave and } \\
\text { longwave radiation components } \\
(R n, G s \downarrow, G s \uparrow, G l \downarrow, G l \uparrow)\left[\mathrm{W} / \mathrm{m}^{2}\right] \text {, } \\
\text { Albedo (a) }[-]) \\
\text { Surface temperature } T_{\text {surf }}\left[{ }^{\circ} \mathrm{C}\right]\end{array}$ & $\begin{array}{l}\text { Special unit for CR1000 for } \\
\text { surface temperature } \\
\text { (New innovation) }\end{array}$ \\
\hline 7. & $\begin{array}{l}\text { Leaf wetness grid, } \\
237-\mathrm{L}\end{array}$ & $3 \mathrm{~cm}$ & Leaf wetness in relative scale & Campbell Scientific \\
\hline 8. & $\begin{array}{l}\text { Soil temperature } \\
\text { (107 thermistor) }\end{array}$ & $\begin{array}{l}-2 \mathrm{~cm} \\
-5 \mathrm{~cm} . \\
-10 \mathrm{~cm} \\
\end{array}$ & $T_{s}\left[{ }^{\circ} \mathrm{C}\right]$ & Campbell Scientific \\
\hline 9. & $\begin{array}{l}\text { Soil wetness } \\
\text { CS616 }\end{array}$ & $-5 \mathrm{~cm}$ & $S w[\operatorname{Trf} \%]$ & Campbell Scientific \\
\hline 10. & $\begin{array}{l}2 \text { Soil heat flux } \\
\text { plates (HFP01) }\end{array}$ & $-8 \mathrm{~cm}$ & $G_{\text {Ssoil }}\left[\mathrm{W} / \mathrm{m}^{2}\right]$ & Huskeflux \\
\hline
\end{tabular}

\subsection{Turbulent fluxes}

We use the eddy covariance technique to calculate fluxes. Eddy covariance is a statistical technique used in micrometeorology to measure high-speed fluxes of momentum, sensible and latent heat, trace gases, and fine aerosol particles within the atmospheric boundary layer. The vertical fluxes are presented as the covariance of vertical wind velocity and the given property. The necessary corrections were calculated by our Fortran program which was tested by comparing different flux calculation algorithms (Weidinger et al., 2002; Weidinger \& Bordás, 2007). The raw turbulent flux of given property $(s)$ can be represented as:

$$
F_{s}=\overline{\rho_{m} W S} .
$$

where $\rho_{m}$ is the density of the moist air; $s$ can be used to represent horizontal velocity components and any scalar parameter like temperature, water vapour content, or concentration of the substance $(c)$ in the air $\left(c=\rho_{c} / \rho_{m}\right)$ and $w$ stands for vertical wind velocity. Flux is equal to the mean product of air density, vertical wind velocity, and the scalar property. 
The momentum and sensible heat fluxes are calculated by deriving the covariance of vertical wind fluctuations with horizontal wind components and temperature, respectively with the assumption of zero mean vertical wind velocity. (The latent heat flux was estimated as the residual term from the energy budget equation in our case). Based on Monin-Obukhov similarity theory and eddy covariance methodology using a few assumptions, the basic equations of momentum and sensible heat fluxes (Arya, 2001; Barcza, 2001; Foken \& Napo, 2008; Burba \& Anderson, 2010):

$$
\begin{aligned}
& \tau=\bar{\rho}_{m}\left({\overline{u^{\prime} w^{\prime}}}^{2}+{\overline{v^{\prime} w^{\prime}}}^{2}\right)^{1 / 2}=\bar{\rho}_{m} u_{*}^{2}=\bar{\rho}_{m} K_{M} \frac{\partial \bar{v}_{h}}{\partial z} \cong \bar{\rho}_{m} K_{M} \frac{\Delta \bar{v}_{h}}{\Delta z}, \quad\left[(\mathrm{~N} / \mathrm{s}) / \mathrm{m}^{2} \mathrm{~s}\right] \\
& H=\bar{\rho}_{m} c_{p m} \overline{w^{\prime} T^{\prime}}=-\bar{\rho}_{m} c_{p m} u_{*} T_{*}=-\bar{\rho}_{m} c_{p m} K_{H} \frac{\partial \bar{T}}{\partial z} \cong-\bar{\rho}_{m} c_{p m} K_{H} \frac{\Delta \bar{T}}{\Delta z},\left[\mathrm{~W} / \mathrm{m}^{2}\right]
\end{aligned}
$$

where $u^{\prime}, v^{\prime}, w^{\prime}, T^{\prime}$ are the fluctuations of wind velocity components and temperature fluctuations, $c_{p m}$ is the specific heat capacity of the moist air in the constant pressure, $K_{M}$, $K_{H}$ are the eddy diffusivity coefficients for momentum and sensible heat, $u_{*}, T_{*}$ are the friction (or dynamical) velocity and dynamical temperature.

\subsection{Results and Discussion}

A total of 24 foggy periods were recorded by the Hungarian Meteorological Service using an on-site web camera from October $15^{\text {th }}$ to December $11^{\text {th }} 2018$ in Siójut. 15 fog events out of the 24 started to develop in the late evening or late night and continued to last till the early morning of the next day. The development of these fog events in the evening or night and dissipation in the morning after the increase of global radiation suggest that these fog events are radiation or radiation driven advection fogs.

The daily variation of half-hourly averages of net radiation $(R n)$, sensible (H_corr.), latent (LE_corr.), and ground heat ( $G$ _Soil) fluxes are shown in Fig. 3 along with foggy periods. According to Fig. 3 from $19^{\text {th }}$ November to $28^{\text {th }}$ November (323-332 DOY) the values of net radiation were practically below $100 \mathrm{~W} / \mathrm{m}^{2}$.

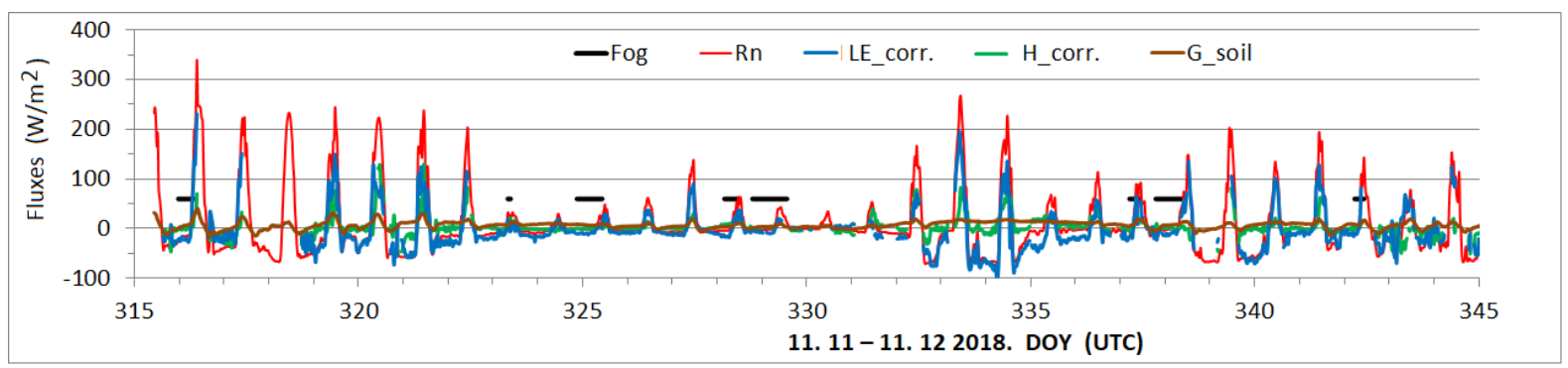

Figure 3. Observed energy budget components and fog events for Siójut Fog Experiment from 11th November to 11th December 2018.

This could be explained on the basis of high cloudiness and precipitation events. Since the net radiation was lower, the values of sensible, latent and soil heat fluxes were also lower during this period. However, before and after this period, the daily maximum of net radiation was above $100 \mathrm{~W} / \mathrm{m}^{2}$ (on a few days more than $200 \mathrm{~W} / \mathrm{m}^{2}$ ). During the whole measuring period the net radiation, sensible, latent and heat flux into the soil ranged between $-70 \mathrm{~W} / \mathrm{m}^{2}$ to $340 \mathrm{~W} / \mathrm{m}^{2},-91$ to $129 \mathrm{~W} / \mathrm{m}^{2},-104$ to $223 \mathrm{~W} / \mathrm{m}^{2}$ and -16 to $40 \mathrm{~W} / \mathrm{m}^{2}$ respectively. It is clear from Fig. 3 that when fog finishes (day time), the net radiation, sensible heat, latent 
heat, and soil fluxes began to rise, and during the fog, night time, their values decrease and become very low.

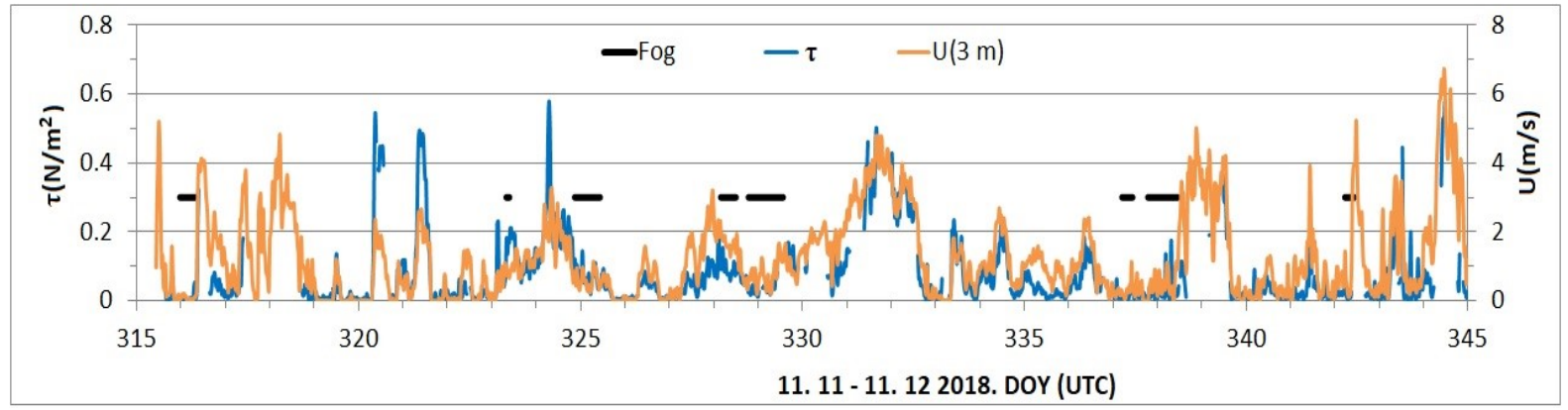

Figure 4. Observed momentum fluxes $(\tau)$, friction velocity $(\mathrm{u} *)$ and wind speed $(\mathrm{U}(3 \mathrm{~m}))$ for Siójut Fog Experiment from 11th November to 11th December 2018.

Fig. 4 shows the daily variation of momentum flux $(\tau)$, friction velocity $(u *)$, and wind speed $(U(3 \mathrm{~m}))$. The values of $\tau, u *$, and $U(3 \mathrm{~m})$ range between 0 to $0.65 \mathrm{~N} / \mathrm{m}^{2}, 0.0$ to $0.7 \mathrm{~m} / \mathrm{s}$ and 0.0 to $7.5 \mathrm{~m} / \mathrm{s}$, respectively. As the fog dissipates during the day, the value of all the 3 variables began to rise due to higher turbulence.

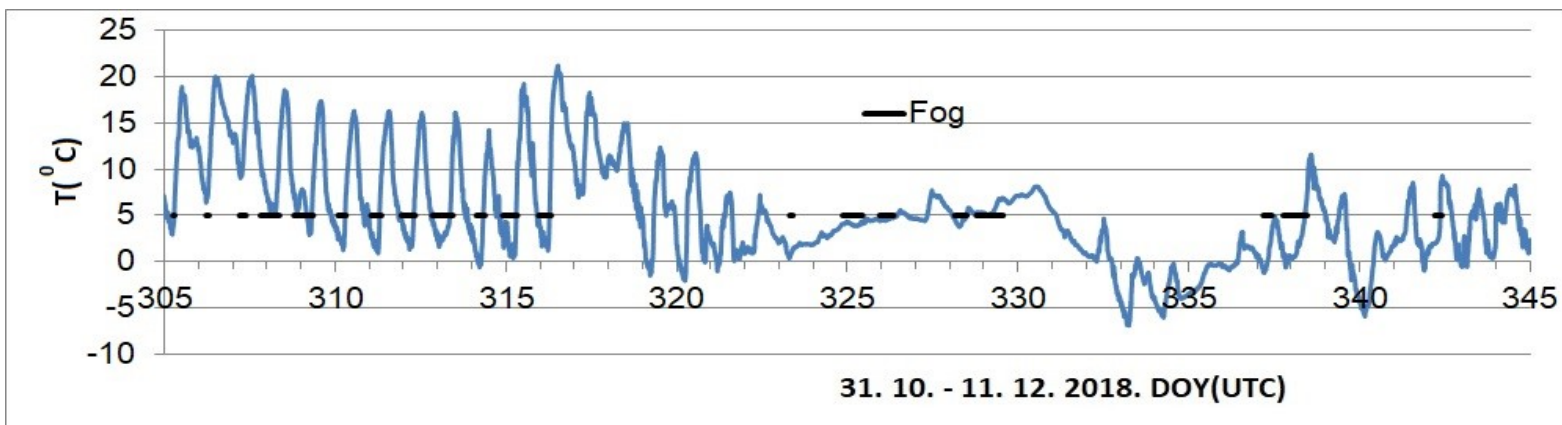

Figure 5. Temperature $(2.7 \mathrm{~m})$ during all the fog events observed in the Siójut Fog Experiment.

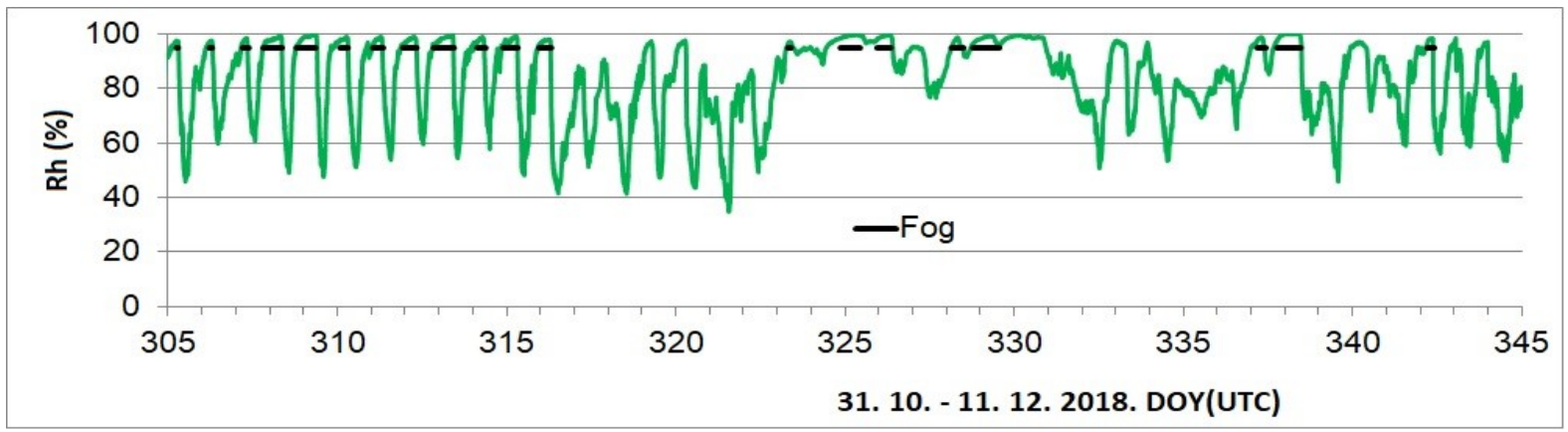

Figure 6. Relative humidity $(2.7 \mathrm{~m})$ during all the fog events observed in the Siójut Fog Experiment.

The daily variation of meteorological variables like air temperature and relative humidity is shown in Figs. 5 and 6 During the night, when the ground is wet due to fog, a parallel rise in the relative humidity reaching $95-100 \%$ and a reduction in temperature can also be observed. Since 15 out of the 24 cases occur during the night, it is clear that radiative heat loss from the ground caused the temperature drop, and this cooling leads to an increase in relative humidity. 


\section{Conclusions}

This study tried to establish a connection between foggy events and micrometeorological parameters with the help of high-resolution micrometeorological measurements and analysis. First, we compared the fog climatology among New Delhi, Siófok, and Budapest. New Delhi had the highest number of mean fog and mist events as well as the respective durations among the 3 cities. December and January were identified as the months with the highest number of mist and fog events as well as their durations for the 3 cities.

We choose the eddy covariance method in order to calculate the momentum and sensible heat fluxes. Based on the soil and radiation budget measurements the heat flux into the soil $\left(G_{-}\right.$Soil $)$and the net radiation $(R n)$ were also calculated. The latent heat flux $(L E)$ was estimated as a residual term using the available energy $\left(R n-G_{-}\right.$Soil $)$and sensible heat flux $(H)$. The mean values of the Bowen ratio $(\beta=H / L E)$ were also estimated $(\sim 0.51)$.

The daily variation of the surface energy budget components during the observation period showed that when the fog dissipated (daytime), the values of energy budget components increased. The variation of meteorological parameters like temperature and relative humidity showed the same pattern. Therefore, we concluded that fog events that occurred during the nights were radiative. As radiation components decreased during the fog events and they only began to rise after the dissipation of the fog during the day.

The flux calculations and micrometeorological measurements results were provided to the University of Pannonia and the University of Pecs for further analysis on fog chemistry and numerical fog modelling (Imre et al., 2019). These measurements can help us to improve parameterization in numerical models for fog prediction to study its evolution and structure in detail.

\section{Financial support}

This research has been supported by the European Regional Development Fund, and the Hungarian Government grant no. GINOP-2.3.2-15-2016-00055 and GINOP-2.3.2-15-201600007.

\section{References}

Arya, P.S., 2001: Introduction to micrometeorology, Academic Press, 420p.

Barcza, Z., 2001: Long-term atmosphere/biosphere exchange of $\mathrm{CO}_{2}$ in Hungary. Ph.D. thesis, Eötvös Loránd University, Budapest. http://nimbus.elte.hu/ bzoli/thesis/index.html

Bottyán, Zs., Deák, B., Wantuch, F., 2010: A látástávolság és a köd rövid távú előrejelzésének lehetőségei. Repüléstudományi Konferencia 2010, Szolnok, 2010. április 16. Repüléstudományi közlemények 2010/2 különszám.

Burba, G., Anderson, D., 2010. A brief practical guide to eddy covariance flux measurements: principles and workflow examples for scientific and industrial applications. Li-Cor Biosciences, USA. ISBN: 978-0-61543013-3 https://doi.org/10.13140/RG.2.1.1626.4161

Foken, T., Napo, C.J., 2008: Micrometeorology, Springer, 159-170.

Ghude, S.D., Bhat, G.S., Prabhakaran, T., Jenamani, R.K., Chate, D.M., Safai, P.D., Karipot, A.K., Konwar, M., Pithani, P., Sinha, V., Rao, P.S.P., Dixit, S.A., Tiwari, S., Todekar, K., Varpe, S., Srivastava, A.K., Bisht, D.S., Murugavel, P., Kaushar Ali, Usha Mina, Dharua, M., Jaya Rao, T., Padmakumari, B., Hazra, A., Nigam, N., Shende, U., Lall, D.M., Chandra, B.P., Mishra, A.K., Kumar, A., Hakkim, H. Pawar, H., Acharja, P., Kulkarnil, R., Subharthi, C., Balaji, B., Varghese, M., Bera, S., Rajeevan, M., 2017: Winter fog experiment over the Indo-Gangetic plains of India. Current Science, 112(4): 767-784. https://doi.org/10.18520/cs/v112/i04/767-784

Gultepe, I., Fernando, H.J.S., Pardyjak, E.R., Hoch, S.W., Silver, Z., Creegan, E., Leo, L.S., Zhaoxia Pu, De Wekker, S.F.J., Chaoxun Hang, 2016: An Overview of the MATERHORN Fog Project: 
Gandhi, A., Gyöngyösi, A.Z., Tordai, V.Á., Torma, P., Rehák, A., Szilágyi, M., Horváth, Á., Weidinger, T.: Micrometeorological measurements on foggy situations in Siójut (November - December, 2018)

Observations and Predictability. Pure and Applied Geophysics, 173: 2983-3010.

https://doi.org/10.1007/s00024-016-1374-0

Haeffelin, M., Bergot, T., Elias, T., Tardif, R., Carrer, D., Chazette, P., Colomb, M., Drobinski, P.,

Dupont, E., Dupont, J-C., Gomes, L., Musson-Genon, L., Pietras, C., Plana-Fattori, A., Protat, A.,

Tangognio, J., Raut, J-C., Rémy, S., Richard, D., Sciare, J., Zhang, X., 2010: PARISFOG:

shedding new light on fog physical processes. Bulletin of American Meteorological Society

(BAMS), 91: 767-778. https://doi.org/10.1175/2009BAMS2671.1

Horváth, L., Koncz, P., Móring, A., Nagy, Z., Pintér, K., Weidinger, T., 2018: An attempt to partition stomatal and non-stomatal ozone deposition parts on a short grassland. Boundary-Layer Meteorology, 162: 1-24. https://doi.org/10.1007/s10546-017-0310-x

Imre, K., Molnár, A., Peterka, A., Geresdi, I., Khumar, J., Ferenczi, Z., Horvath, A., Weidinger, T., Gelencsér, A., 2019: Characterization of particle-droplet interactions in wintertime fog in Hungary: results of an intensive monitoring campaign. IFDA2019-2, 2 p. abstracts. https://meetings.copernicus.org/ifda2019/IFDA2019-2-abstracts.pdf

Liu, T., Marlier, M. E., Defries, R. S., Westerveldt, D. M., Xia, K. R., Fiore, A. M., Mickley, L. J., Cusworth, D. H., Milly, G., 2018: Seasonal impact of regional outdoor biomass burning on air pollution in three Indian cities: Delhi, Bengaluru, and Pune. Atmospheric Environment, 172: 83-92. https://doi.org/10.1016/j.atmosenv.2017.10.024

Mauder, M., Foken, T., 2015: Documentation and instruction manual of the eddy-covariance software package TK3 (update). 67p. Arbeitsergebnisse, Universität Bayreuth, Abt. Mikrometeorologie. Internet, ISSN 1614-8924 http://www.bayceer.uni-bayreuth.de/mm/

Michaelides, S., Leviäkangas, P., Doll, C. Heyndrickx, C., 2014: Foreward: EU-funded projects on extreme and high-impact weather challenging European transport systems. Natural Hazards, 72 : 5-22. https://doi.org/10.1007/s11069-013-1007-1

Tuba, Z., Bottyán, Zs., 2018: Fuzzy logic-based analogue forecasting and hybrid modelling of horizontal visibility. Meteorology and Atmospheric Physics, 130: 265-277. https://doi.org/10.1007/s00703-017-0513-1

Vajda, A., Tuomenvirta, H., Juga, I., Nurmi, P., Jokinen, P., Rauhala, J., 2014: Severe weather affecting European transport systems: the identification, classification and frequencies of events. Natural Hazards, 72: 169-188. https://doi.org/10.1007/s11069-013-0895-4

Wantuch, F., Michaelides, S., 2005: Comparing different visibility forecast methods referring to Larnaca Airport Cyprus. COST 722-Short-range forecasting methods of fog, visibility and low clouds. Symposium. Abstracts, Larnaca Cyprus. 2005.

Weidinger, T., Ács, F., Mészáros, R., Barcza, Z., 1999: Energy budget components in a forest clear cut: analysis of measurement results. Idöjárás, 103: 145-160.

Weidinger, T., Barcza, Z., Matyasovszky, I., 2002: Turbulens áram számító programok összehasonlítása az EBEX-2000 mérési expedíció adatai alapján. Levegő-növény-talaj rendszer. Debreceni Egyetem Agrártudományi Centrum. Lícium-Art Könyvkiadó, 121-128.

Weidinger, T., Bordás, Á., 2007: A felszínközeli légréteg és a planetáris határréteg kutatásának föbb kérdései. Felhőfizika és mikrometeorológia, 32. Meteorológiai Tudományos Napok 2006.

(Szerkesztette: Weidinger T. és Geresdi I.), Országos Meteorológiai Szolgálat, Budapest, 105-124.

Westerhuis, S., Fuhrer, O., Cermak, J., Eugster, W., 2020: Identifying the key challenges for fog and low stratus forecasting in complex terrain. Quarterly Journal of the Royal Meteorological Society, 146: 3347-3367. https://doi.org/10.1002/qj.3849

\section{ORCID}

Tordai A. V. (iD https://orcid.org/0000-0002-8617-0531

Torma $P$. (D) https://orcid.org/0000-0001-9282-6931

Horváth Á. (D) https://orcid.org/0000-0002-5724-3869

Weidinger T. (D) https://orcid.org/0000-0001-7500-6579 